UDC 33

\title{
FORMATION OF CUSTOMARY VILLAGE: A CASE STUDY OF TAMKESI CUSTOMARY VILLAGE PREPARATION IN SUB DISTRICT OF SOUTHERN BIBOKI DISTRICT, NORTH TIMOR CENTER
}

\author{
Abi Kristoforus*, Djaha Ajis Salim Adang, Kase Petrus \\ Master Program in Administrative Science, Graduate Program, \\ University of Nusa Cendana Kupang, Nusa Tenggara Timur, Indonesia \\ *E-mail: bikomiutara@gmail.com
}

\begin{abstract}
This research was conducted to identify the fulfillment of requirements for the customary village formation of Tamkesi preparation; (1) Village with common law community unit and their traditional rights are still valid, whether they are territorial, genealogical or functional. Unity of the law community still has territory and at least fulfills one or a combination of elements of (a) a society whose citizens share a common sense in the group (b) customary administrative institutions (c) customary property and/or objects and/or (d) tools of customary law norms. (2) The unity of indigenous and tribal peoples together with their traditional rights in accordance with community development. Its existence has been acknowledged under the law as a reflection of the development of values considered ideal in today's society, both in general and sectoral laws. The substance of the traditional right is recognized and respected by the citizens of the unity of the community concerned and the wider society and not contrary to human rights. (3) The unity of indigenous and tribal peoples shall be in accordance with the principle The Unitary State of the Republic of Indonesia. Customary law and its traditional rights do not interfere with the existence of the Unitary State of the Republic of Indonesia as a political unity and legal unity. Customary law and its traditional rights do not threaten the sovereignty and integrity of the Unitary State of the Republic of Indonesia. The substance of customary law norms is appropriate and not contrary to the provisions of the legislation. (4) Design a model of customary village of Tamkesi preparation that meets the requirements by finding the complete structure of customary village government with authority, main task, function of each government element; designing a model of working relationships between elements of customary village governance, a model of custom village government relationships with other institutions within indigenous villages.
\end{abstract}

\section{KEY WORDS}

Customary village, customs, culture, village.

In the General Explanation of Law Number 6 the Year, 2014 regarding the Village described that the Village or the so-called by another name has existed before the formation of the Unitary State of the Republic of Indonesia. As a proof of its existence, the Elucidation of Article 18 of the 1945 Constitution (before the amendment) states that; "In the territory of the State of Indonesia there are approximately 250 "Zelfbesturende landschappen" and "Volksgemenenschappen" such as villages in Java and Bali, Nagari in Minangkabau, Dusun and clan in Palembang and so on. These areas have their original structure and can, therefore, be considered special areas.

Furthermore, in Article 18B (the amendment of the 1945 Constitution), it states that, "The State recognizes and respects the unity of indigenous and tribal peoples along with their traditional rights as long as they are alive and in accordance with the development of society and the principle of the Unitary State of the Republic of Indonesia regulated in law . "The first law specifically regulating the village is Law No. 5 of 1974. In Law Number 5 Year 1974 , it is stated that the village is an area occupied by a number of residents as a unity of society, including the unity of the legal community which has the lowest organization directly under the head of the sub-district and is entitled to conduct its own household affairs within the ties of the Unitary State of the Republic of Indonesia. 
UU no. 6 in 2014 gives spaces to District/City Government for rearrange the village and set it in two types, namely "Desa" or "Desa Adat" no later than one year after the enactment of Law no. 6 in 2014. To carry out orders of these UU, a careful assessment needs to be done to the existing village today for enactment into the indigenous village with due regard to the conditions laid down in Article 97.

North Central Timor District Government recognizes the importance and necessity of preserving the cultural values and customs of rural communities in the area of North Central Timor District. Therefore the North Central Timor District Government has responded positively to the wishes of Tautpah Village Village of South Biboki Subdistrict to split the Tautpah village into two villages namely Tautpah and Tamkesi Adat villages in order to maintain and preserve the cultural values and customs of Sonaf Tamkesi. As a proof of the seriousness of the North Central Timor District Government by the wishes of the Tautpah community, in 2005 Kuan Tamkesi (Kampung Tamkesi) was established as a customary village with the Decree of North Timor District Regent No. 502 of 2005 on the Stipulation of Indigenous Villages Preparation of Tamkesi Kecamatan South Biboki, dated July 19, 2005. Unfortunately, Desa Adat Preparation of Tamkesi should have become a definitive custom village, since its formation has been more than 5 (five) years, but until now; "Kuan Adat Tamkesi" still retains the status of the customary village of preparation. This is clearly detrimental to indigenous people of traditional villages of Tamkesi preparation, hence indigenous peoples of Kuan Adat Tamkesi has repeatedly urged the Government of TTU Regency to immediately establish Kuan Adat Tamkesi to be the definitive custom village.

\section{LITERATURE REVIEW}

Customary Villages. In Law No.6 of 2014, customary villages or the so-called customary law community units that have territorial boundaries and are authorized to regulate and administer the government affairs and local community interests based on the community initiatives, origin rights, and/or traditional rights recognized and respected in the government system of the Unitary State of the Republic of Indonesia.

Further provisions in Article 97 of Law No.6 of 2014 states that the status of a village can be converted into a customary village if it meets a number of conditions, covering that: (a) the customary law community units along with its traditional rights are still alive/ exist, either the territorial, genealogical, as well as functional ones; (b) the customary law community units along with its traditional rights, are seen in accordance with the community development; and (c) the customary law community units along with its traditional rights are in line with the principles of the Unitary State of the Republic of Indonesia.

The customary law community units along with its traditional rights which are still alive/ exist must have a territory and at least meet one of or a combination of the elements consisting of (a) communities whose people have a common feeling within it; (b) (b) customary governance institution; (c) wealth and/ or customary objects; and/ or (d) customary law norms.

The customary law community units along with its traditional rights are seen in accordance with the community development of (a) the existence has been acknowledged by the applicable law as a reflection of the development of values considered ideal in today's communities, both general and sectoral laws; and (b) the substance of traditional rights is recognized and respected by the people of the customary law community units and the wider community, as well as not contrary to human rights.

Customary Law Communities. According to Kusuma (2003:106), customary law communities or alliance are largely still alive/ exist with their own customary laws based on territorial or genealogical bonds, and/ or a mixture of both genealogical-territorial. The Territorial Law Community is a fixed and orderly community whose members are bound to a certain locality, either in the worldly connection as a place of life or the spiritual connection as a place of worshipping the ancestral spirit. The territorial law alliance can be divided into three categories: Village Alliance, District Alliance, and United Villages. Meanwhile, the Genealogical Law Community is an orderly community unit, whose members are bound to 
the same lineage of one ancestor, either directly due to blood relationship or indirectly due to a marriage or customary relationship/ bond. In the Dutch East Indies age, the genealogical community is divided into three categories, namely: patrilineal community, matrilineal community, and bilateral/ parental community.

Customs. Customs mean habit-based practices both individually or in groups. Customs are formed throughout history. The origin and character are influenced by the characteristics of a nation, the conditions of natural climates, the social position of individuals, religious views and so on. Customs have a power from a social custom/ habit and affect people's behaviour (Bagus, 2002). Koentjaraningrat (1987:19) defines customs as the ideal form of cultures that functions as a code of conduct. Violations of customs can be in the form of receiving or not customary reactions. Customary reactions can be either moral sanctions or social sanctions.

Customs (in the Regulation of the State Minister of the Republic of Indonesia No.3 of 1997 ) is defined as a set of values or norms, rules, and social beliefs that grow and develop along with the growth and development of rural communities and/ or other community units. Moreover, it is also meant as other values or norms that are still lived and maintained as manifested in various patterns of behaviours that are the habits in the life of communities. Habits in the life of communities are patterns of activities or deeds done by the people, which is a unit of a particular law community that basically can derive from the customary law or customs as recognized by the people and other communities, and still prevails in the life of the community.

Customary Community Solidarity. Solidarity is defined as togetherness, cohesiveness, compactness, empathy, sympathy, and tolerance (the National Education Department, 2008). Social solidarity is the main theme spoken by Durkheim as a moral source for shaping social order in a community. Durkheim also states that the origin of the moral authority should be traced down to something rather vague which he calls as "community".

Durkheim (Johnson, 1986: 183) produces two related concepts for his explanation of social reality. The concepts are "collective conscience " and "collective representation". Collective representation (images) are symbols that have the same meaning for all members of a group and enable them to feel as one another as members of the group. Collective representation (images) shows the ways group members see themselves in their relationships with objects that affect them. Collective representation is part of the content of collective liability. The collective conscience contains all ideas shared by individual members of a community and which become collective goals and intentions (Campbell, 2010). Durkheim (in Johnson, 1986) divides social solidarity into two groups, namely mechanical and organic solidarity. Mechanical solidarity is based on a "collective consciousness/ conscience", which refers to "the totality of common beliefs and sentiments that are averagely on the same people.

Customary Governance Institutions. Institutions are defined as the official system of social behaviour as well as the customs or norm governing the behaviour and all of its equipment for various human complexes in communities (The National Education Department, 2008). Customary Institutions are institutions born of customary values that are respected, acknowledged, and obeyed by communities (Article 1 No. 15 from Law No. 7 of 2012 concerning Social Conflict Handling). In Article 18 B Paragraph (2), it is stated that the Government recognizes and respects customary law community units along with its traditional rights as long as it is alive/ exist and in accordance with the community development and the principles of the Unitary State of the Republic of Indonesia as governed by law. Then, in Article 28 I Paragraph (3), it is stated that cultural identities and traditional community rights are respected in harmony with the times and civilization growth.

\section{METHODS OF RESEARCH}

This research used a qualitative approach with a case study type. The focuses of this research were: (1) Law community units; (2) Customary community solidarity; (3) Customary Governance Institutions; (4) Wealth and/ or customary objects; (5) Customary law norm 
devices; and (6) Village authority and right use. This research was conducted in the preparation customary village of Tamkesi, South Biboki District, North Central Timor Regency. Data of this research were collected by interviews, observation, and documentation techniques. The data were collected through informants chosen purposively (certain considerations).

\section{RESULTS AND DISSCUSION}

Customary Community Solidarity. Social solidarity is the main theme spoken by Durkheim as a moral source for shaping social order in communities. Durkheim stated that the origin or moral authority must be traced down to something rather vague which he calls as "community". Durkheim produces two related concepts for his explanation of social reality. The concepts are "collective conscience " and "collective representation". Collective representation (images) are symbols that have the same meaning for all members of a group and enable them to feel as one another as members of the group. Collective representation (images) shows the ways group members see themselves in their relationships with objects that affect them.

The results showed that the customary community solidarity of Kuan Tamkesi are still well-preserved. It is because the composition of the population of Kuan Tamkesi is mostly from Usboko tribe which in the customary structure is a King (Usif). King (Usif) is the highest position in the custom structure of Tamkesi. The majority of the population of descendants of the King (Usif), of course, must provide examples and models of a good and true community life in every way. The solidarity sense of the customary community of Tamkesi that is still well-preserved up to date has made Kuan Tamkesi as a Customary Village that is highly respected by anyone who visits Kuan Tamkesi.

Customary Governance Institutions. Positions/ occupations that existed during the traditional reign are presented in this following table.

Table 1 - Name of Position and Tribe of Those Who Served

\begin{tabular}{|c|l|l|l|}
\hline No. & \multicolumn{1}{|c|}{ Name of Position } & \multicolumn{1}{|c|}{ Tribe } & \multicolumn{1}{|c|}{ Clan } \\
\hline 1. & Usif/Kesel (King) & Tautpah & Usboko \\
\hline 2. & Mafefa/Spokesperson & Uskenat & Uskenat \\
\hline 3. & Amaf & Taslulu-Tkafun & Taslulu-Tkafun \\
\hline 4. & Meo/Warlord & Taslulu-Tkafun & Taslulu-Tkafun \\
\hline 5. & News Anchor of Usif (Opas/Hae Usif) & Ta'haf/Tsiomlasi & Ta'haf \\
\hline 6. & Servants in Sonaf & Suni-Banuan & Suni-Banuan \\
\hline
\end{tabular}

Source: Research Results.

The revitalization and re-functionalization of the positions and its officials in Sonaf Tamkesi neighbourhood need to be conducted so that the customary stakeholders in Sonaf Tamkesi can be well-accommodated. The results indicate that the governance structure of the existing customary village has not yet accommodated the actual customary stakeholders in Tamkesi. The customary governance institution in Tamkesi can be seen in Table 2 below.

Table 2 - Customary Governance Institution of Sonaf Tamkesi

\begin{tabular}{|c|l|l|l|}
\hline No. & \multicolumn{1}{|c|}{ Name of Position } & \multicolumn{1}{|c|}{ Stakeholder } & \multicolumn{1}{c|}{ Tribe } \\
\hline 1. & Kesel Biboki/Usif (King) & Usboko & Tautpah \\
\hline 2. & Mafefa/ Spokesperson & Uskenat & Uskenat \\
\hline 3. & Amaf/Tobe & Paisanaunu-Belsikone & Paisanaunu-Belsikone \\
\hline 4. & Meo/ Warlord & Taslulu-Tkafun & Taslulu-Tkafun \\
\hline 5. & News Anchor of Usif to amaf & Ta'haf & Ta'haf \\
\hline 6. & Servants in Sonaf & Suni-Banuan & Suni-Banuan \\
\hline
\end{tabular}

Source: Research Results.

The positions existed during the traditional reign can be seen in this following table. 
Eurasia: Economics \& Business, 5(11), May 2018

DOI https://doi.org/10.18551/econeurasia.2018-05

Table 3 - Name of Position and Tribe of Those Who Served

\begin{tabular}{|c|l|l|l|}
\hline No. & \multicolumn{1}{|c|}{ Name of Position } & \multicolumn{1}{|c|}{ Tribe } \\
\hline 1. & Usif/Kesel (King) & Tautpah & Usboko \\
\hline 2. & Mafefa/ Spokesperson & Uskenat & Uskenat \\
\hline 3. & Amaf & Taslulu-Tkafun & Taslulu-Tkafun \\
\hline 4. & Meo/ Warlord & Taslulu-Tkafun & Taslulu-Tkafun \\
\hline 5. & News Anchor of Usif (Opas/Hae Usif) & Ta'haf/Tsiomlasi & Ta'haf \\
\hline 6. & Servants in Sonaf & Suni-Banuan & Suni-Banuan \\
\hline
\end{tabular}

Source: Research Results.

The revitalization and re-functionalization of the positions and its officials in Sonaf Tamkesi neighbourhood need to be conducted so that the customary stakeholders in Sonaf Tamkesi can be well-accommodated. The results indicate that the governance structure of the existing customary village has not yet accommodated the actual customary stakeholders in Tamkesi. The customary governance institution in Tamkesi can be seen in Table 4 below.

Table 4 - Customary Governance Institution of Sonaf Tamkesi

\begin{tabular}{|c|l|l|l|}
\hline No. & \multicolumn{1}{|c|}{ Name of Position } & \multicolumn{1}{|c|}{ Stakeholder } & \multicolumn{1}{c|}{ Tribe } \\
\hline 1. & Kesel Biboki/Usif (King) & Usboko & Tautpah \\
\hline 2. & Mafefa/ Spokesperson & Uskenat & Uskenat \\
\hline 3. & Amaf/Tobe & Paisanaunu-Belsikone & Paisanaunu-Belsikone \\
\hline 4. & Meo/ Warlord & Taslulu-Tkafun & Taslulu-Tkafun \\
\hline 5. & News Anchor of Usif to amaf & Ta'haf & Ta'haf \\
\hline 6. & Servants in Sonaf & Suni-Banuan & Suni-Banuan \\
\hline
\end{tabular}

Source: Research Results.

The data in Table 2 above is a customary governance institution that applies to all Biboki territory The customary governance institution is meant to run only for customary affairs which is routinely carried out every year, namely: The Customary Ritual of Tatam Pentaud ma Aen Tauf (a customary ritual of putting Tributes to Sonaf) in which all tribes that exist in all Biboki territory both the original people or immigrants living in Biboki land (especially farmers) must give tributes to Kesel Biboki (Biboki's King). The tributes are in the form of 1 (one) kg paddy rice, 1 (one) bunch corn (16/24 puler) and money as much as 10,000 IDR per Head of Family. All the heads of farmer and Civil Servant Families who have a garden or paddy field (farmland) in Biboki land must give tributes as described above.

After all the tribes deliver the tributes, Kesel Biboki (Biboki's King) will set a special day for the Customary Ritual in order to give blessings to all the existing tribes known as "TsiomManikin Oetene" from Kesel Biboki.

Table 5 - Governance Institution of Preparation Customary Village of Tamkesi

\begin{tabular}{|c|l|l|l|}
\hline No. & \multicolumn{1}{|c|}{ Name of Position } & \multicolumn{1}{|c|}{ Stakeholder } & \multicolumn{1}{|c|}{ Tribe } \\
\hline 1. & Ana Pah & Usboko & Tautpah \\
\hline 2. & Aluanta/ Clerk/ Secretary & Usboko & Tautpah \\
\hline \multirow{2}{*}{3.} & A'haba 1(Kaur 1) & Usboko & Tautpah \\
& A'haba 2 (kaur 2) & Usboko & Tautpah \\
\hline \multirow{2}{*}{4.} & Ahaba 3 (kaur 3) & Taslulu & Taslulu \\
\hline \multirow{2}{*}{5.} & Meo Sapan 1(Kasie 1) & Taslulu & Taslulu \\
& Nakaf 1 (Kadus 1) & Tkafun & Tkafun \\
\hline & Nakaf 2 (Kadus 2) & Uskenat & Uskenat \\
\hline
\end{tabular}

Source: Research Results.

The data in Table 5 illustrates that the customary governance institution in the Preparation Customary Village of Tamkesi has not accommodated the actual customary stakeholders as described in Table 2 above. The existing fact says that either Ana Pah (the Customary Village Head) or other apparatus of customary village governance are only 
representatives of the tribes that exist and do not involve the actual customary functionaries although they are still alive/ exist. This is not in accordance with what is actually desired by Law No.6 of 2014 concerning Villages. Such conditions can be improved by revitalizing and re-functionalizing the existing customary governance institutions.

Indigenous Property/Customary Objects possessing mystical Magical powers. Sonaf Tamkesi is well known throughout TTU District even abroad because of the authenticity of traditional house building and the contents of the custom house in the form of magical objects that have magical powers. The miraculous objects referred to are as follows:

1. Muti Ajaib (Magic necklace) consisting of ten leaves of muti but 1 head or center/ pendant. Muti or necklace referred to is called magical because it consists of ten necklaces but one head or center/ pendant and emit a beautiful golden light and always move.

2. The other four Muti leaves are used as a means of customary ritual to ask for help and protection from the Almighty so that Tamkesi society is given sufficient rain and heat every year and is spared from all kinds of disasters.

3. A natural weighing device (Besi/Iron Tai Pah) is a piece of metal that used to be used to find the right place for the establishment of the center of the kingdom of Biboki. The object is working like a GPS.

4. Four Natural Stone Pillars in front of Sonaf Tamkesi (Nii) entrance and exit that can speak like a human when a visitor arrives has evil intentions, so the guest will be surprised and confused because there is no human being around the entrance and exit but the voice of the person talking sounded clear. The sound that sounded gave a kind of alert because there were enemies that threatened the security of Sonaf Tamkesi and instantly it would look like so many war army ready with swords and spears in their hands. This will make the intended guest maliciously fearful and run scarce so that his evil intentions cannot be implemented.

Customary Law Norms Device. Customary Law Norms Device that regulates agriculture and food security, livestock, forestry, plantation (mamar), mining, home industry and trade, fishery and marine, health, education and culture, spatial/settlement/housing arrangement, environment, tourism , land, marriage and association of young people, are as follows:

The Customary Legals Norm Device that regulates Agriculture and Food Security. In the affairs of agriculture and food security, there are customary rules that must be obeyed by all indigenous peoples namely;

Custom Rituals Tafek Nonoh Hau Ana (Taetuf Manine); Initial rituals when people start exemption of shrubs for agriculture (gardens/fields) and rice fields. Everyone who has married at the beginning just started to open the fields of the fields/fields or rice fields, must first perform customary rituals for permission and participation and blessings from the Almighty through the spirits of the ancestors by offering at least 1 (one) red male cock, equipped with 1 (one) bottle of wine, betel nut as necessary and rice (1) tenasak.

Traditional Ritual Sua'ap Nonoh Hau Ana; custom rituals that must be done before burning gardens/fields. The intention in this customary ritual is to ask for protection to make the gardens or fields that have been completed cut and ready to be burned can burn out and the fire does not spread to other locations that could endanger human life as well as livestock community. This customary ritual is done jointly. In this customary ritual, sacrificial animal is only 1 (one) pig/goat.

Traditional Ritual of Tsifo Nopo; custom rituals that must be done after the burning of the garden/fields is completed. Intention in traditional rituals are asking a blessing of nature and ancestors to cool the atmosphere and heat conditions during combustion or gardens, to plant rice, corn and others can flourish and avoid the danger of drought. The sacrificial animal in this traditional ritual is only 1 (one) pig/goat. All custom rituals as described above, became the authority of Ama Tobe. Therefore, Ama Tobe has a great responsibility to succeed all the custom rituals intended.

Tsiom Manikin Oetene Custom Ritual (Fua Ton); The customary ritual of Tsiom Manikin Oetene or Fua Ton is an customary ritual which must be followed by all Head of the 
Family from all tribes either domiciled in the village, or outside the village. The customary ritual was done in November after all the tribes took their tributes to Sonaf Tamkesi.

Bunuk Hau mate is a customary norm that must be obeyed by all citizens Tamkesi that is not to cut raw wood what else cut down the trees that still live in the forest during the west season is February - March.

Legal Devices name, arrangement procedures, sanctions and rewards:

Table 6 - Device Name of Customary Law Norms per Field of Affairs

\begin{tabular}{|c|l|l|l|}
\hline No & \multicolumn{1}{|c|}{ Field Affairs } & \multicolumn{1}{|c|}{ Device Name of Customary Law Norm } & \multicolumn{1}{|c|}{ Person in charge } \\
\hline 1. & Agriculture & $\begin{array}{l}\text { Tafek Nonoh Hau ana } \\
\text { Bribe Nonoh Hau ana } \\
\text { Sifo Nopo } \\
\text { Fua Ton }\end{array}$ & Ama Tobe \\
\hline 2. & Forestry & $\begin{array}{l}\text { Bunuk Hau Mate } \\
\text { Bunuk Mui Fuij } \\
\text { Bunuk Kaun Oel }\end{array}$ & $\begin{array}{l}\text { Ama Tobe } \\
\text { Ama Tobe } \\
\text { Kabu Oel }\end{array}$ \\
\hline 3. & Plantation (mamar) & Bunuk Hau Fua & Kabu Oel \\
\hline 4. & Marriage & $\begin{array}{l}\text { Bake Hau no'o/Oanaf } \\
\text { Mam Mnasi } \\
\text { Puah naek Manus naek }\end{array}$ & $\begin{array}{l}\text { The parents of both the prospective bride and } \\
\text { Atoin Amaf. }\end{array}$ \\
\hline 5. & Youth association & Tpao ma tpanak aok nonok ma aok bian & Youngsters \\
\hline 6. & Living environment & $\begin{array}{l}\text { Bunuk Hau Mate } \\
\text { Bunuk Mui Fuij }\end{array}$ & Anoanta (Tobe) \\
\hline 7. & Farms & Oemata hun naka mese mese,. & Anoanta (Tobe) \\
\hline 8. & Heritage & Bui susu/bnak am honi ain honi & The eldest son \\
\hline 9. & Trading & Oapamnes & Seller of cattle \\
\hline
\end{tabular}

Source: Research Results.

The data in table 6 above illustrates that each area of affairs has its own device name of customary law norms.

The authority and traditional rights of traditional villages which are being used. The traditional powers and rights that are being used in managing village affairs are:

1. The authority and right to collect tribute annually from all tribes and/or all households in the Biboki area.

2. The authority and right to collect tribute when there are Tamkesi citizens who sell cattle, pigs or goats and collect money on customary village administration.

3. The authority and rights and obligations facilitate the customary rituals of Tafek Nonoh Hau Ana, Su'ap Nonoh Hau Ana, Sifo Nopo and Fua Ton.

4. Authority and Rights oversee the preservation of the environment, customary forests and water sources in Tamkesi.

The authority and traditional rights in taking care of those affairs have been taken over by the top level government. Traditional powers and rights in relation to matters which have been taken over by the upper-level government are in the forestry sector. In relation to forest affairs in both ordinary forests and customary forests, customary village Preparation of Tamkesi still exercises its authority and traditional rights because the traditional forest in Tamkesi is a forest that has magical mystical powers till now. All citizens Tamkesi allowed to cut trees both living and dried in the customary forest area/sacred forest/jungle pemali called; "Naes Leu" Not only wood but also all kinds of animals including community forest. If someone break the rules then the stakes are the life of the person itself and this is already known by all Tamkesi society and society outside Tamkesi.

Rights that are judged to be contrary to the authority and rights of the upper-level government. Rights that are judged to be contrary to the authority and right of the upper-level government but still adhered to by the entire Biboki community are the authority and right to levy an annual tribute for inclusion in Sonaf Tamkesi. In addition, there is also the authority and traditional rights to collect tribute when there are citizens who sell cattle, goats or pigs.

Village Customary Rights Preparation of Tamkesi that is difficult to use by Customary Village Government Preparation Tamkesi because constrained by a number of rules at the top level. The rights that until now cannot be obtained by the Customary Village Government 
Preparation Tamkesi is the right to get the Village Fund from the state budget. The obstacle faced at this time is not yet definitively customary village Preparation Tamkesi

\section{CONCLUSION}

Based on the research data and discussion of the focus and sub-focus of this thesis research, it can be explained that the answer to this research hypothesis is that Kuan Tamkesi is qualified and deserves to be upgraded as a definitive Indigenous Village in Timor Tengah Regency. While concerning How to Design Model Kuan Tamkesi as a Customary Village need to be repaired and adjusted so that the customary stakeholders in Kuan Tamkesi custom territory get the portion as it should. Authors suggest several things as follow: North Central Timor District Government should immediately prepare the draft of Local Regulation (Ranperda) on the Determination of Kuan Tamkesi as the Definitive Customary Village. Kuan Tamkesi Model Design as Customary Village needs to be adjusted so that the actual customary stakeholders can be given a role in the structure of the Tamkesi Customary Government Institution.

\section{REFERENCES}

1. Kusuma, N., \& Agustina, F. (2003). Gelombang Perlawanan Rakyat - Kasus-kasus Gerakan Sosial di Indonesia. Yogyakarta: INSIST Press.

2. Bagus, L. (2002). Kamus Filsafat. Jakarta: Gramedia Pustaka Utama.

3. Koentjaraningrat. (1987). Sejarah Teori Antropologi. Jakarta: UI-Press.

4. Johnson, D. P. (1986). Teori Sosiologi Klasik dan Modern. Jakarta: PT. Gramedia.

5. Campbell, N. A., \& Reece, J. B. (2010). Biologi (8th Ed). Translated by Damaring Tyas Wulandari, S.Si. Jakarta: Erlangga.

6. Depdiknas. (2008). Kamus Besar Bahasa Indonesia. Jakarta: Gramedia Pustaka Indonesia. 